\title{
IMPLEMENTASI PERATURAN DAERAH NOMOR 10/ 2010 TENTANG PENGELOLAAN SAMPAH (STUDI KASUS DI KOTA MALANG)
}

\section{IMPLEMENTATION OF THE LOCAL REGULATION NO. 10/ 2010 ABOUT WASTE MANAGEMENT (CASE STUDY IN MALANG CITY)}

\author{
Oleh: \\ Retno Wulan Sekarsari ${ }^{1)}$, Khoiriyah Trianti ${ }^{2)}$ \\ ${ }^{1)}$ Fakultas Ilmu Administrasi, Universitas Islam Malang, \\ ${ }^{2)}$ Fakultas Ilmu Administrasi Universitas Islam Malang \\ Email : $\underline{\text { sekarsari@unisma.ac.id }}{ }^{1)}$, ria13er@gmail.com ${ }^{2)}$
}

\begin{abstract}
Abstrak
Undang-Undang Nomor 18 Tahun 2008 tentang Pengelolaan Sampah serta Peraturan Pemerintah Nomor 81 Tahun 2012 mengamanatkan perlunya perubahan paradigma yang mendasar dalam pengelolaan sampah yaitu dari paradigma kumpul- angkut-buang, menjadi pengolahan yang bertumpu pada pengurangan sampah dan penanganan sampah. Sampah bisa dimanfaatkan sebagai sumber daya yang mempunyai nilai ekonomis. Pemanfaatan tersebut misalnya, untuk energi terbarukan, kompos, pupuk, dan bahan baku industri.

Berdasarkan masalah yang diangkat dalam penelitian yang menekankan pada proses dan makna, maka bentuk penelitian yang digunakan adalah penelitian kualitatif yang bersifat deskriptif dengan maksud memberikan gambaran masalah secara sistematis, cermat, rinci, dan mendalam mengenai implementasi Perda Kota Malang No. 10 Tahun 2010 dalam penyelenggaraan pengelolaan sampah yang diterapkan kota Malang.

Mekanisme pengelolaan sampah Kota Malang adalah sebagai berikut: Penyapuan Pewadahan - Pengumpulan - Pemindahan - Pengangkutan - Pembuangan akhir dan Pengelolaan Sampah dengan Pengkomposan. Metode memilah sampah berbeda-beda tergantung dari jenis sampah. BSM melakukan pemilahan untuk membagi sampah dengan metode 3R. Reduce (mengurangi sampah) yaitu tidak membiarkan tumpukan sampah yang berlebih. Reuse (memanfaatkan) yaitu menggunakan kembali sampah yang bisa digunakan dan Recycle (mendaur ulang) sampah merupakan program untuk memanfaatkan kembali sampah setelah mengalami proses pengolahan.

Pemerintah terus melakukan upaya pengelolaan sampah menggunakan konsep 3R (Reduce, Reuse, Recycle). Kegiatan ini dibuktikan dengan adanya Bank Sampah Malang, Pengkomposan, dukungan kepada pemulung. Pemerintah selalu berupaya memberikan edukasi kepada masyarakat tentang pengelolaan sampah rumah tangga dan sadar untuk membuang sampah pada tempatnya. Pemerintah dan masyarakat perlu membuat dan memberikan sanksi terhadap pelanggar aturan.
\end{abstract}

Kata Kunci: Implementasi, Peraturan Daerah, Pengelolaan Sampah. 


\begin{abstract}
The Constitution no.18/2010 about waste management, and Local Regulation No.81/2012 emphasize new paradigm in waste management, namely from the collect garbage - hauling garbage - throw garbage, into waste management that focus on Reduce, Reuse of garbages. Waste can be used as a resource that has economic value. The utilization of the garbages can be used as renewable energy, compost, fertilizer, and industrial raw materials.

Based on the urgency of the research, this research emphasizing of process and meaning. The researcher using descriptive qualitative research, that will describe a systematic, careful, detailed, and in-depth description of the problem of research especially about implementation of the local regulation no. 10/ 2010 about waste management in Malang city.

The mechanism of waste management in Malang City is as follows: Sweeping Collecting - Moving up the garbage to Final disposal and Waste Management by Composting the garbage. The method of sorting waste has many variation depending on the type of waste. BSM does sorting to divide waste by the $3 R$ method, that are Reduce the garbage - Reuse the garbage - using the garbage as Recycle Product that supported by Local Government of Malang City. The government of Malang City continues to implement waste management using the $3 R$ concept (Reduce, Reuse, Recycle). This activity involves Malang Garbage Bank, Composting, supporting scavengers. The Local government of Malang City always trying to educate the society and household about the right concept of waste management. The government and society also need to make punishment and sanction to the violators.
\end{abstract}

Keywords: Implementation, Local Regulation, Waste Management. 


\section{PENDAHULUAN}

Sampah dan limbah telah menjadi permasalahan nasional. Masalah persampahan sangat terkait dengan pertambahan penduduk, pertumbuhan ekonomi dan perubahan pola konsumsi asyarakat. Pertumbuhan pesat di sektor industri juga merupakan imbas dari meningkatnya pendapatan rumah tangga dan makin beragamnya pola serta jenis konsumsi masyarakat. Kondisi tersebut menimbulkan bertambahnya volume, beragamnya jenis, dan karakteristik sampah dan limbah.

Timbulan sampah dan buangan limbah berdampak buruk bagi lingkungan dan kesehatan, oleh karena itu perlu dilakukan langkah penanganan. Penanganan sampah dan limbah ini sejalan dengan target Sustainable Development Goals (SDGs). Regulasi dalam menangani permasalahan sampah dan limbah tertuang dalam UU Nomor 18 tahun 2008 tentang pengelolaan sampah dan turunannya, serta Undang-Undang Nomor 32 Tahun 2009 tentang Perlindungan dan Pengelolaan Lingkungan Hidup.

Upaya yang dilakukan pemerintah diantaranya dengan mengalokasikan anggaran perlindungan lingkungan pada APBN dan APBD. Penanganan sampah dan limbah juga perlu didukung sarana dan prasarana yang memadai.
Upaya pengelolaan sampah juga dilakukan dengan mendorong pemimpin daerah membangun partisipasi aktif masyarakat serta dunia usaha untuk mewujudkan kota berkelanjutan melalui program Adipura. Menumbuhkan kepedulian terhadap lingkungan perlu dilakukan oleh semua kalangan, pemerintah, swasta dan terutama masyarakat sebagai penyumbang dan penerima ekses negatif pencemaran. Untuk itu masyarakat harus mengambil peran dalam pengurangan dan penanganan sampah.

Kota Malang merupakan salah satu kota besar di Indonesia. Penduduk Kota Malang semakin meningkat dari tahun ke tahun. Berdasarkan data dari Badan Pusat Statistik Kota Malang tahun 2020 penduduk Kota Malang berjumlah 874.890 jiwa. Setiap tahun mengalami peningkatan sebesar 1\% tahun 2019 jumlah penduduk 870.682 jiwa, tahun 2018 866.118, tahun 2017 berjumlah 861.414 jiwa. Jumlah ini belum ditambah jumlah pendatang. Pendatang yang banyak melakukan studi di kota Malang. Peningkatan penduduk ini juga berpengaruh terhadap volume sampah di Kota Malang. Volume sampah di kota Malang semakin meningkat dari tahun ke tahun.

Usaha yang telah dilakukan oleh Dinas Kebersihan Kota Malang selama ini dalam penanganan sampah dan tugas 
pokok lainnya dipandang masih belum optimal. Hal tersebut dibuktikan dengan adanya perbedaan jumlah volume yang diangkut dan diolah hasilnya berbeda dengan volume sampah yang ada. Tindakan penanganan sampah yang kurang baik berakibat buruk terhadap lingkungan hidup, baik pada tanah, air, dan udara. Pembakaran sampah yang dilakukan untuk mengurangi timbunan sampah dapat mencemari udara dan meningkatkan produksi gas rumah kaca, terutama karbondioksida, dan gas metana.

Undang-Undang Nomor 18 Tahun 2008 tentang Pengelolaan Sampah serta Peraturan Pemerintah Nomor 81 Tahun 2012 mengamanatkan perlunya perubahan paradigma yang mendasar dalam pengelolaan sampah yaitu dari paradigma kumpul - angkut - buang, menjadi pengolahan yang bertumpu pada pengurangan sampah dan penanganan sampah. Pengelolaan sampah dapat dilakukan dengan pendekatan yang komprehensif. Dimulai dari hulu, yaitu sejak suatu produk yang berpotensi menjadi sampah belum dihasilkan. Dilanjutkan sampai ke hilir, yaitu pada fase produk sudah digunakan, sehingga menjadi sampah, yang kemudian dikembalikan ke media lingkungan secara aman.

Kegiatan pengurangan sampah bertujuan agar seluruh lapisan masyarakat, melaksanakan kegiatan pembatasan timbulan sampah, pendauran ulang dan pemanfaatan kembali sampah (Reduce, Reuse dan Recycle (3R)). Meskipun demikian, kegiatan 3R ini masih menghadapi kendala utama, yaitu rendahnya kesadaran masyarakat untuk memilah sampah.

Pembangunan bank sampah ini merupakan momentum awal dalam membina kesadaran kolektif masyarakat untuk mulai memilah, mendaur-ulang, dan memanfaatkan sampah. Peran Bank Sampah menjadi penting dengan terbitnya Peraturan Pemerintah (PP) Nomor 81 Tahun 2012 tentang Pengelolaan Sampah Rumah Tangga dan Sampah Sejenis Sampah Rumah Tangga. Akan tetapi, hal tersebut dinilai belum merata ke seluruh masyarakat di Kota Malang, karena Bank Sampah hanya muncul di salah satu daerah saja yaitu RW 03 Sukun Kota Malang. Hal tersebut hanya dapat dirasakan manfaatnya oleh warga sekitar. Belum meratanya program pemerintah pengelolaan sampah berbasis masyarakat, maka penelitian ini muncul untuk melihat bagaimana implementasi kebijakan pengelolaan sampah di Malang.

Pengelolaan sampah rumah tangga belum menjadi priorits di dalam kegiatan masyarakat perkotaan saat ini. Peningkatan jumlah penduduk dan perubahan pola konsumsi telah mengarah pada 
peningkatan volume sampah di Kota Malang. Oleh karena itu, diperlukan suatu sistem pengelolaan sampah berkelanjutan yang berdasarkan pada partisipasi masyarakat dalam program pemerintah.

Penelitian ini akan membahas tentang: Sistem pengelola sampah di Kota Malang menurut Perda No.10 tahun 2010 dan Implementasi kebijakan pengelolaan sampah yang ada di Kota Malang.

\section{TINJAUAN TEORITIS}

\subsection{Kebijakan}

Kebijakan dapat didefinisikan sebagai serangkaian rencana program, aktivitas, aksi, keputusan, sikap, untuk bertindak maupun tidak bertindak yang dilakukan oleh para pihak (aktor-aktor), sebagai tahapan untuk penyelesaian masalah yang dihadapi. Penetapan kebijakan merupakan suatu faktor penting bagi organisasi untuk mencapai tujuannya (Iskandar, 2012).

Lebih lanjut, kebijakan memiliki dua aspek (Thoha, 2012), yakni:

a. Kebijakan merupakan praktika sosial, kebijakan bukan event yang tunggal atau terisolir. Dengan demikian, kebijakan merupakan sesuatu yang dihasilkan pemerintah yang dirumuskan berdasarkan dari segala kejadian yang terjadi di masyarakat. Kejadian tersebut ini tumbuh dalam praktika kehidupan kemasyarakatan, dan bukan merupakan peristiwa yang berdiri sendiri, terisolasi, dan asing bagi masyarakat.

b. Kebijakan adalah suatu respon atas peristiwa yang terjadi, baik untuk menciptakan harmoni dari pihak-pihak yang berkonflik, maupun menciptakan insentif atas tindakan bersama bagi para pihak yang mendapatkan perlakuan yang tidak rasional atas usaha bersama tersebut.

Dengan demikian, kebijakan dapat dinyatakan sebagai usaha untuk mencapai tujuan-tujuan tertentu, sekaligus sebagai upaya pemecahan masalah dengan menggunakan sarana-sarana tertentu, dan dalam tahapan waktu tertentu. Kebijakan umumnya bersifat mendasar, karena kebijakan hanya menggariskan pedoman umum sebagai landasan bertindak dalam usaha mencapai tujuan yang telah ditetapkan.

Kebijakan ini diikuti dan dilaksanakan oleh para pelaku (stakeholders) dalam rangka memecahkan suatu permasalahan tertentu (Haerul, Akib, \& Hamdan, 2016). Proses kebijakan dapat dijelaskan sebagai suatu sistem, yang meliputi: input, proses, dan output. Input kebijakan merupakan isu kebijakan atau agenda pemerintah, sedangkan proses kebijakan berwujud perumusan formulasi kebijakan dan pelaksanaan kebijakan. Isu dan formulasi kebijakan dapat dipahami sebagai proses politik yang dilakukan elit politik dan/ atau 
kelompok-kelompok penekan. Output dari proses kebijakan adalah kinerja kebijakan (Wahyudi, 2016). Oleh karena itu, kebijakan tidak bersifat permanen. Kebijakan dibuat sekali untuk rentang waktu tertentu sebagai sebuah solusi atas permasalahan yang ada dan kepentingannya melayani (Godin, Rein, \& Moran, 2006).

\subsection{Implementasi Kebijakan}

Implementasi kebijakan menunjuk aktivitas menjalankan kebijakan dalam ranah senyatanya, baik yang dilakukan oleh pemerintah maupun pihak yang telah ditentukan dalam kebijakan. Implementasi kebijakan sendiri biasanya ada yang disebut sebagai pihak implementator dan kelompok sasaran. Implementataor kebijakan adalah mereka yang secara resmi diakui sebagai individu/ lembaga yang bertanggungjawab atas pelaksanaan program di lapangan. Kelompok sasaran adalah menunjuk parapihak yang dijadikan sebagai objek kebijakan (Indiahono, 2009: 143)

Van Meter dan Van Horn dalam Winarno (2008: 146-147) membatasi implementasi kebijakan sebagai tindakantindakan yang dilakukan oleh individuindidvidu (atau kelompok-kelompok) pemerintahan maupun swasta yang diarahkan untuk mencapai tujuan-tujuan yang telah ditetapkan dalam keputusankeputusan kebijakan sebelumnya.
Tindakan ini mencakup usaha untuk mengubah keputusan menjadi tindakan operasional dalam jangka waktu tertentu maupun dalam rangka melanjutkan usahausaha untuk pencapaian perubahanperubahan besar dan kecil yang ditetapkan oleh keputusan-keputusan kebijakan.

Menurut Anderson (1979: 68) ada 4 aspek yang perlu dikaji dalam implementasi kebijakan yaitu: (1) Siapa yang mengimplementasikan, (2) Hakikat dari proses administrasi (3) Kepatuhan dan (4) Dampak dari pelaksanaan kebijakan.

\subsection{Pengelolaan Sampah Rumah Tangga}

Pengelolaan sampah, menurut Undang-undang No.18 Tahun 2008 tentang Pengelolaan Sampah, adalah suatu kegiatan mengurangi dan menangani sampah yang sistematis, menyeluruh, dan berkesinambungan yang meliputi pengurangan dan penanganan sampah. Undang-undang tersebut juga menegaskan bahwa pengelolaan sampah harus dilakukan secara komprehensif dari hulu sampai hilir.

Kegiatan mengurangi dan menangani sampah terkait erat dengan konsep 3R, yang terdiri atas:

1. Reduce (mengurangi timbulan sampah), yaitu mengurangi kegiatan konsumsi yang menyebabkan timbulan sampah.

2. Reuse (menggunakan kembali bahan yang berpotensi 
menimbulkan sampah), yaitu penggunaan kembali sampah secara langsung, baik untuk fungsi yang sama maupun fungsi yang lain.

3. Recycle (mendaur ulang sampah), yaitu memanfaatkan kembali sampah setelah mengalami proses pengolahan

\subsection{Peraturan Daerah Kota Malang}

\section{Nomor 10 Tahun 2010}

Peraturan Daerah Kota Malang Nomor 10 Tahun 2010 menimbang bahwa permasalahan sampah telah menjadi permasalahan nasional sehingga pengelolaannya perlu dilakukan secara komprehensif dan terpadu dari hulu ke hilir agar memberikan manfaat secara ekonomi, sehat bagi masyarakat, dan aman bagi lingkungan, serta dapat mengubah perilaku masyarakat. Sampah adalah sisa kegiatan sehari-hari manusia. Sampah yang dikelola berdasarkan Peraturan Daerah ini, terdiri atas; a) sampah rumah tangga, (b) sampah sejenis sampah rumah tangga, (c) sampah spesifik. Sampah spesifik sebagaimana dimaksud pada ayat (1) huruf c, meliputi: sampah yang mengandung bahan berbahaya dan beracun; sampah yang mengandung limbah bahan berbahaya dan beracun; sampah yang timbul akibat bencana; puing bongkaran bangunan; sampah yang secara teknologi belum dapat diolah; dan/atau sampah yang timbul secara tidak periodik.

Pasal 7 Perda Kota Malang Nomor 10 Tahun 2010 menjelaskan tugas Pemerintah Daerah sebagaimana dimaksud, terdiri atas: (a) menumbuh kembangkan dan meningkatkan kesadaran masyarakat dalam pengelolaan sampah; (b) melakukan penelitian dan pengembangan teknologi pengurangan serta penanganan sampah; (c) memfasilitasi, mengembangkan dan melaksanakan upaya pengurangan, penanganan dan pemanfaatan sampah; (d) melaksanakan pengelolaan sampah serta memfasilitasi sarana dan prasarana pengelolaan sampah; (e) memfasilitasi dan melakukan pengembangan atas manfaat yang dihasilkan dari pengelolaan sampah; (f) memfasilitasi penerapan teknologi spesifik lokal yang berkembang pada masyarakat setempat untuk menangani dan mengurangi sampah; dan (g) melakukan koordinasi antar Satuan Kerja Perangkat Daerah, masyarakat dan dunia usaha agar terdapat keterpaduan dalam pengelolaan sampah.

Pasal 16 menyebutkan bahwa pengelolaan sampah rumah tangga dan sampah sejenis rumah tangga terdiri atas pengurangan sampah dan penanganan sampah. Hal ini diperinci dalam pasal 17 yang mana penguranan sampah yang dimaksud adalah pembatasan timbulan sampah, pendauran ulang sampah, dan 
pemanfaatan kembali sampah. Lebih lanjut di dalam Pasal 17 dijelaskan bahwa Pemerintah Daerah wajib melakukan kegiatan sebagai berikut: (a) menetapkan target pengurangan sampah secara bertahap dalam jangka waktu tertentu: (b) memfasilitasi penerapan teknologi yang ramah lingkungan; (c) memfasilitasi penerapan label produk yang ramah lingkungan; (d) memfasilitasi kegiatan mendaur ulang dan mengguna ulang; dan (e) memfasilitasi pemasaran produkproduk daur ulang.

Hal ini juga dijelaskan dalam Pasal 18 bahwa untuk pengurangan sampah Pemerintah Daerah dapat melakukan:

a. menentukan kawasan atau lokasi percontohan untuk pengurangan sampah dengan teknologi yang ramah lingkungan dan kegiatan mendaur ulang serta mengguna ulang;

b. membentuk dan menentukan kaderkader pengelolaan sampah ditiap-tiap RW atau Kelurahan sebagai pelopor langsung yang terjun di masyarakat dalam pengurangan sampah.

\section{METODE PENELITIAN}

\subsection{Mekanisme Penelitian}

Berdasarkan masalah yang diangkat dalam penelitian yang menekankan pada proses dan makna, maka bentuk penelitian yang digunakan adalah penelitian kualitatif yang bersifat deskriptif dengan maksud memberikan gambaran masalah secara sistematis, cermat, rinci, dan mendalam mengenai implementasi Perda Kota Malang No. 10 Tahun 2010 dalam penyelenggaraan pengelolaan sampah yang diterapkan kota Malang.

Jenis penelitian yang digunaka adalah penelitian deskripstif kualitatif. Sebagai suatu penelitian deskriptif, penelitian ini studi kasusnya mengarah pada pendeskripsian secara rinci dan mendalam mengenai potret kondisi tentang apa yang sebenarnya terjadi di lapangan studinya.

\subsection{Instrumen Penelitian}

Terdapat dua hal utama yang mempengaruhi kualitas hasil penelitian, yaitu kualitas instrumen utamanya adalah peneliti sendiri, namun selanjutnya setelah fokus penelitian menjadi jelas, maka kemungkinan akan dikembangkan instrumen penelitian yang diharapkan dapat melengkapi data dan membandingkan dengan data yang telah ditemukan melalui:

1. Teknik Observasi

2. Teknik Wawancara

3. Teknik Dokumentasi

\subsection{Lokasi Penelitian}

Penelitian ini mengambil lokasi di Dinas Kebersihan dan Pertamanan Kota Malang. Alasan pemilihan lokasi tersebut antara lain: (1) Pada Dinas Kebersihan dan Pertamanan Kota Malang merupakan unsur pelaksana pemerintah daerah yang 
menangani masalah kebersihan dan pertamanan kota, salah satunya mempunyai tugas yang sangat penting dalam penyelenggaraan pengelolaan sampah. Sehingga pada dinas tersebut peneliti bisa mendapatkan data-data yang diperlukan dengan permasalahan yang ada. (2) Lokasi tersebut merupakan tempat dimana proses implementasi kebijakan (Peraturan Daerah Kota Malang Nomor 10 Tahun 2010) dalam penyelenggaraan pengelolaan sampah dilaksanakan. (3) Masyarakat Kota Malang

\subsection{Objek Penelitian}

Di dalam penelitian ini penulis memilih informan dan berbagai sumber yang terkait dengan pengelolaan sampah khususnya di Kota Malang. Informasi diambil dari orang-orang yang dipilih oleh peneliti yang berperan sebagai narasumber dan partisipan. Dengan pertimbangan, bahwa informan tersebut sepenuhnya terlibat dalam kasus pada situasi sosial yang hendak diteliti.

Ada beberapa informan dan informasi kunci yang menjadi sumber informasi penulis dalam penellitian ini, yaitu:

1. Kepala Dinas Kebersihan Kota Malang

2. Pejabat Pelaksana Teknis Kegiatan (PPTK) Program Pegembangan Kinerja Pengelolaan Persampahan

3. Petugas Lapangan, yang terdiri dari Petugas Kebersihan Pasar, Penyapu Jalan, Petugas Pembersih Parit dan
Rumput, Petugas Pembersih Pengangkut Sampah, Petugas Pemeliharaan TPA

4. Masyarakat Kota Malang secara umum dan secara khusus yang tinggal di dekat TPA.

\section{HASIL DAN PEMBAHASAN}

4.1 Sistem Pengolahan Sampah di Kota Malang menurut Perda No.10 tahun 2010

Timbunan sampah di Kota Malang akan terus bertambah. Jumlahnya terus bertambah seiring dengan pertambahan penduduk dan perubahan kondisi perekonomian. Di tahun 2019, jumlah sampah yang diangkut sebanyak 667 ton per hari. Kota Malang memiliki 72 TPS. Seluruh sampah langsung dikelola. Sebagian sampah sudah diproses baik komposting maupun pemilahan dan daur ulang di Rumah PKD (Pilah Kompos Daur Ulang). Sejumlah 25 PKD lokasinya berdekatan dengan TPS.

Kota Malang menghasilkan sampah sebanyak 667 ton/ hari. 667 ton sampah diangkut oleh 151 truk/ hari. 1 truk mengangkut 4-5 ton sampah. Pengelolaan sampah di Kota Malang dikelola oleh Dinas Lingkungan Hidup dulunya adalah Dinas Kebersihan dan Pertamanan Kota Malang. Organisasi Dinas Lingkungan Hidu Kota Malang diatur dalam Peraturan Daerah Nomor 10 tahun 2010 tentang 
pembentukan, kedudukan,tugas pokok, fungsi dan struktur organisasi dinas sebagai pelaksana pemerintah daerah. Mekanisme pengelolaan sampah Kota Malang adalah sebagai berikut:

1. Penyapuan. Penyapuan sampah merupakan kegiatan awal pengelolaan sampah dari sumber sampah, baik sampah dari rumah tangga, perusahaan, kantor, jalan raya, dan lain-lain. Kegiatan awal pengelolaan sampah ini dilakukan setiap hari agar Kota Malang Mkelihatan bersih , indah, nyaman dan sehat. Petugas pasukan kuning dinas kebersihan Kota Malang yang bertugas menyapu sampah di jalur poros di pusat wilayah kota dibagi menjadi empat kelompok jam kerja yaitu: Pukul 05.00 - 09.00 WIB; pukul $10.00-13.00$ WIB; dan pukul 14.00 - 17.00 WIB; dan pukul $19.00-21.00 \mathrm{WIB}$.

2. Pewadahan. Pewadahan sampah merupakan sarana tempat penampungan sampah pada setiap lokasi sumber sampah. Sistem pewadahan sampah dapat bersifat individual atau bekelompok. Bentuk pewadahan sampah yang diterapkan di Kota Malang bervariasi, untuk wadah individual menggunakan bak pasangan batu-bata yang diletakkan di depan rumah, wadah sampah dari ban bekas, tong sampah, keranjang sampah, kantong plastik dan bak sampah.

3. Pengumpulan. Pengumpulan sampah dari tempat-tempat sampah yang ada di tempat atau di wadah sampah yang ada di sumber sampah dilakukan oleh petugas pengumpulan sampah, dalam hal ini pasukan kuning, baik yang swakelola maupun dinas kebersihan kota, untuk mengumpulkan sampah ke TPS-TPS dengan menggunakan gerobak sampah.

4. Pemindahan. Pemindahan sampah dilakukan oleh pasukan kuning untuk memindahkan sampah dari dalam gerobak untuk dimasukkan ke dalam container atau dump truck, pemindahan dilakukan untuk sampah yang sudah dikumpulkan pasukan kuning. Sistem pemindahan sampah di Kota Malang dapat berupa andasan dengan bantuan alat pengangkut loader dan dump truck, container dengan alat arm roll truck dan transfer depo dengan rumah jaga yang dilengkapi dengan dump truck memindahan pengosongan sampah gerobak.

5. Pengangkutan. Pengangkutan sampah adalah kegiatan sampah yang telah di kumpulkan di tempat penampungan sementara atau langsung dari tempat sumber sampah ke tempat pembuangan akhir. Pengangkutan sampah dari TPS (tempat pembuangan sementara) ke TPA (tempat pembuangan akhir) dilaksanakan oleh dinas kebersihan Kota Malang dengan menggunakan 3 angkutan meliputi: loader, dump truck, dan arm roll dalam proses pemuatannya. 
6. Pembuangan akhir. Pembuangan akhir adalah cara yang digunakan untuk memusnahkan sampah padat dari hasil kegiatan pengumpulan sampah dan pengangkutan sampah. Sistem pengelolaan sampah di TPA Supit Urang menggunakan sistem controlled landfill. Sistem controlled landfill merupakan peningkatan dari open dumping.

Untuk mengurangi potensi gangguan lingkungan yang ditimbulkan, sampah ditimbun dengan lapisan tanah setiap tiga hari sekali. Dalam operasionalnya, untuk meningkatkan efisiensi pemanfaatan lahan dan kestabilan permukan TPA, maka dilakukan juga perataan dan pemadatan sampah menggunakan alat berat.. Akan tetapi, pemerintah menyadari penggunaan sistem controlled landfill sudah dirasa tidak dapat mengatasi banyaknya sampah yang ada di TPA. Hal ini diperlukan sistem pengelolaan sampah yakni menggunakan sistem sanitary landfill. Sistem sanitary landfill dilakukan secara sistematis yakni seperti proses penyebaran dan pemadatan sampah pada area pengurugan dan penutupan sampah dilakukan setiap hari. Hal ini dilakukan untuk meminimalkan potensi gangguan yang ditimbulkan. Sistem sanitary landfill masih tahap proses pembangunan, yang nantinya di tahun 2021 Kota Malang akan menerapkan sistem sanitary landfill.
Selain sistem buang, angkut, tumpuk ada juga proses pemilaha. Pemilahan dilakukan secara manual yakni diambil oleh pemulung. Pemulung itu sendiri dari warga sekitar. Pemulung tersebut mengambil sampah yang masih bisa dijual. Pemilahan ini juga dilakukan di area TPA Supit Urang. Partisipasi pemulung dalam upaya pengurangan sampah di TPA juga berdampak secara ekonomis dan ekologis. Pada saat truck pengangkut sampah yang datang di TPA Supit Urang, sampahnya dibongkar dan dikeluarkan semuanya, para pemulung berkelompok dan secara individu "mengumpulkan" semua sampah yang dianggap mempunyai nilai ekonomis dan dimasukkan ke dalam keranjang anyaman bambu yang dibawanya.

Dari semua jenis sampah yang terkumpul di keranjang bambu masingmasing pemulung kemudian di bawa ke rumah gudang sementara yang berada di lingkungan TPA Supit Urang, kemudian di pilah-pilah sesuai dengan karakter sampah yang ada.

Dari sejumlah sampah yang dikumpulkan dan dimasukkan ke dalam keranjang bambu masingmasing pemulung, mayoritas adalah sampah anorganik, berupa: plastik, besi, kertas, rambut dan lainnya. Sampah ini merupakan barang yang jika ditimbun sulit terurai dan membutuhkan waktu yang sangat lama untuk melapiknya. Dalam hal 
ini para pemulung mempunyai andil yang sangat besar secara ekologis karena mengurangi volume sampah yang dibuang ke lingkungan bebas dan berpeluang menimbulkan dampak kesehatan lingkungan bagi masyarakat di sekitar TPA Supit Urang. Partisipasi pemulung ini didukung oleh pemerintah. Dukungan tersebut yakni dibangun Bank Sampah Malang II yang dikhsuskan kepada pemulung. Jadi, nanti pemulung-pemulung bisa menyetorkan hasil pengumpulan sampahnya berdasarkan karakter masingmasing ke Bank Sampah Malang II yang letaknya di dekat TPA Supit Urang.

\section{Pengelolaan Sampah dengan Pengkomposan.}

Pembuatan kompos juga dilakukan dalam upaya pengurangan sampah. Kompos ini berasal dari sampah organik yaitu sampah dari pasar. Sampah dari pasar ini berupa sampah sisa-sisa sayuran yang sudah tidak digunakan, kemudian diolah menjadi kompos. Dari 667 ton sampah, pengkomposan ini mampu mengurangi 10 ton sampah per hari yang digunakan menjadi kompos. Kemudian kompos ini juga dibagikan kepada masyarakat yang membutuhkan. Biasanya pengelola TPST bekerjasama dengan sekolah-sekolah. Dari kerjasama ini juga ditujukan untuk memberikan edukasi kepada masyarakat bahwa sampah dapat menjadi sesuatu yang bnerguna bagi masyarakat.
Kota Malang telah melakukan konsep 3R. Dalam upayanya melakukan 3R (reduce, reuse, recycle) kota Malang memiliki Bank Sampah yaitu Bank Sampah Induk Gemaripah. Bank sampah ini adalah bank sampah pertama kali yang ada di kota Malang. Bank Sampah ini merupakan program pemerintah dalam upaya mengurangi jumlah sampah dan menyadarkan masyarakat akan pentingnya menjaga lingkungan.

\subsection{Implementasi Kebijakan}

Pengelolaan Sampah Yang Ada Di Kota Malang

a) Mekanisme Pengelolaan Sampah Bank Sampah Masyarakat

Pengelolaan sampah merupakan suatu kegiatan yang dilakukan untuk menangani sampah secara sistematis, menyeluruh, dan berkesinambungan sejak sampah ditimbulkan sampai dengan pembuangan akhir. Secara garis besar pengurangan dan penanganan sampah meliputi pengendalian timbunan sampah, pengumpulan sampah, transfer dan transport, pengelolaan hingga pembuangan akhir.

Metode memilah sampah berbedabeda tergantung dari jenis sampah. BSM melakukan pemilahan untuk membagi sampah dengan metode 3R. Reduce (mengurangi sampah) yaitu tidak membiarkan tumpukan sampah yang berlebih. Reuse (memanfaatkan) yaitu 
menggunakan kembali sampah yang bisa digunakan dan Recycle (mendaur ulang) sampah merupakan program untuk memanfaatkan kembali sampah setelah mengalami proses pengolahan.

a. Pemilahan Sampah dan Stok Sampah

$$
\text { Kegiatan pemilahan sampah }
$$
dimaksudkan agar memudahkan petugas untuk mengolah sampah yang telah dikumpulkan. Hal ini bermanfaat agar pekerjaan lebih efisien dan tidak memakan banyak waktu untuk memilah kembali. Pemilahan sampah yang dilakukan BSM dilakukan melalui beberapa tahapan yaitu sampah tersebut dibawa petugas pengambilan sampah hingga sampah yang diolah akan dibeli oleh pihak pabrik untuk diolah kembali. Berikut ini gambar mekanisme pemilahan/sortir sampah yang dilakukan oleh BSM.

Bagan 4. Struktur Mekanisme Pemilahan/Sortir Sampah di BSM

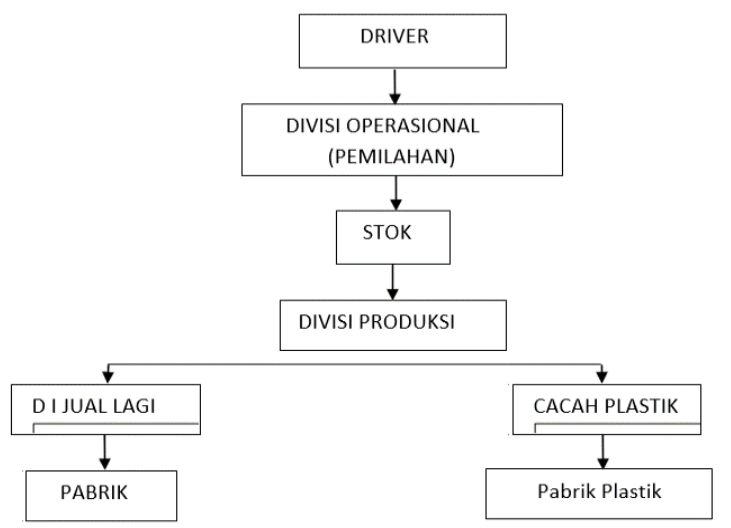

Pada gambar diatas, sampah yang dibawa oleh driver atau petugas pengambilan sampah terlebih dahulu ditimbang serta dijumlahkan menurut jenis sampah yaitu nasabah instansi, sekolah, masyarakat. Lalu sampah yang ada di BSM selanjutnya akan dilakukan pengklarifikasian berdasarkan jenisnya kemudian dilakukan pembersihan. Untuk bagian pemilahan akan dilakukan oleh divisi operasional. Proses pemilahan dan packing barang dilakukan oleh divisi operasional tetapi untuk jenis sampah kertas sesuai dengan jenis yang ditentukan. Selanjutnya, disiapkan dalam bahan baku produksi akan dimasukkan ke dalam stok sampah siap giling yang nantinya akan dicacah maupun dijual kembali akan diproses pada divisi produksi. Sampah yang telah terkumpul nantinya akan diklasifikasikan berdasarkan kamar sampah atau gudang yang telah diberi skat/pembatas. Sampah yang ada di kamar-kamar di tumpuk secara rapi dimasukkan ke dalam karungkarung. Untuk sampah yang akan digiling dilakukan pembersihan tetapi bukan dicuci melainkan dibersihkan dari label. Seperti botol air mineral akan dibersihkan dari label merk air tersebut. Sampah yang banyak di BSM adalah jenis plastik karena terdapat fasilitas pencacahan plastik hingga akhirnya sampah bersih siap diproses untuk digiling dan masuk ke dalam stok sampah yang dimiliki BSM untuk proses selanjutnya. Tahap selanjutnya, divisi operasional akan memutasi sampah yang siap digiling ke 
divisi produksi Berikut ini gambar proses pembersihan sampah oleh BSM:

\section{Gambar.1: Pembersihan dari label dan Contoh Hasil Produksi Sampah}

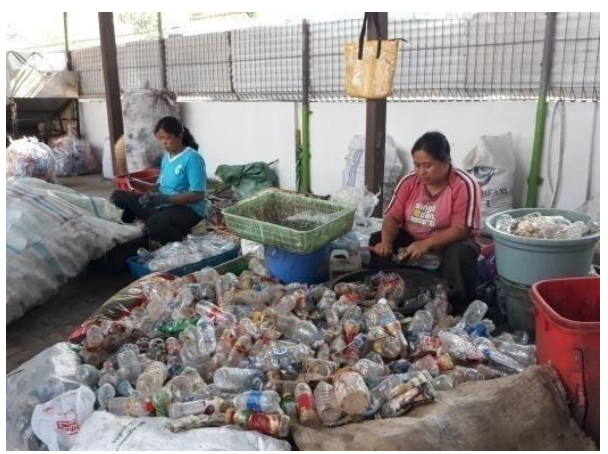

Sumber: Dokumentasi Peneliti (2020)

Gambar.2: Hasil Produksi Bank

Sampah

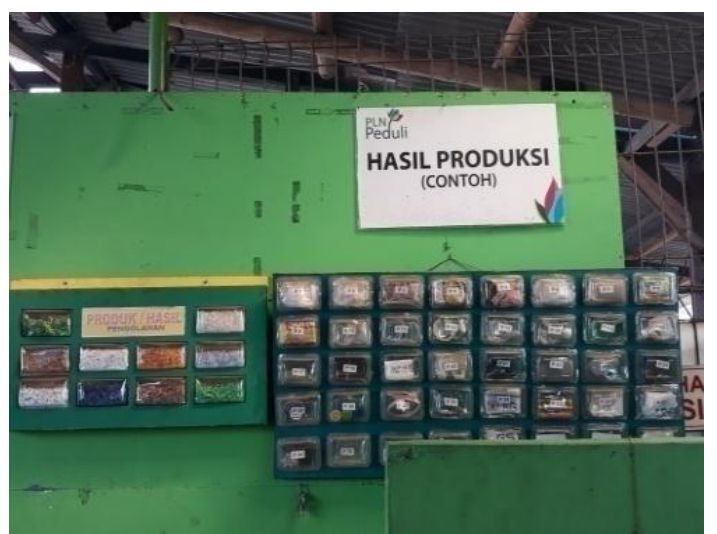

Sumber: Dokumentasi Peneliti (2020)

Pada divisi produksi ini penggilingan, pengeringan, dan packing hasil giling akan menjadi tanggung jawab divisi ini. Pada proses penggilingan/cacah plastik yang bertanggung jawab terhadap proses penggilingan hingga perawatan mesin penggiling. Sebagian sampah akan diolah menjadi cacahan. Proses pertama, sampah tersebut dimasukkan ke mesin pencacahan sekaligus dilakukan pencucian. Setelah dilakukan pencacahan diteruskan dengan pengeringan menggunakan mesin sentries/blower. Dari hasil pengeringan menggunakan mesin sentries/blower tersebut hasil cacahan tidak kering 100 persen tetapi masih agak basah yaitu kering sekitar $80 \%$, sehingga perlu mengeringkan dengan dihamparkan atau di angin-anginkan selama satu hari. Selanjutnya setelah dihamparkan, hasil cacahan plastik tersebut dimasukkan ke dalam karung. Lalu seksi pengering dan packing akan menimbang dan mencatat hasil produksi yang sudah dipacking dan melaporkan ke manager produksi untuk siap dijual ke pabrik plastik yang memesan.

Gambar 3. Proses Pencacahan Plastik
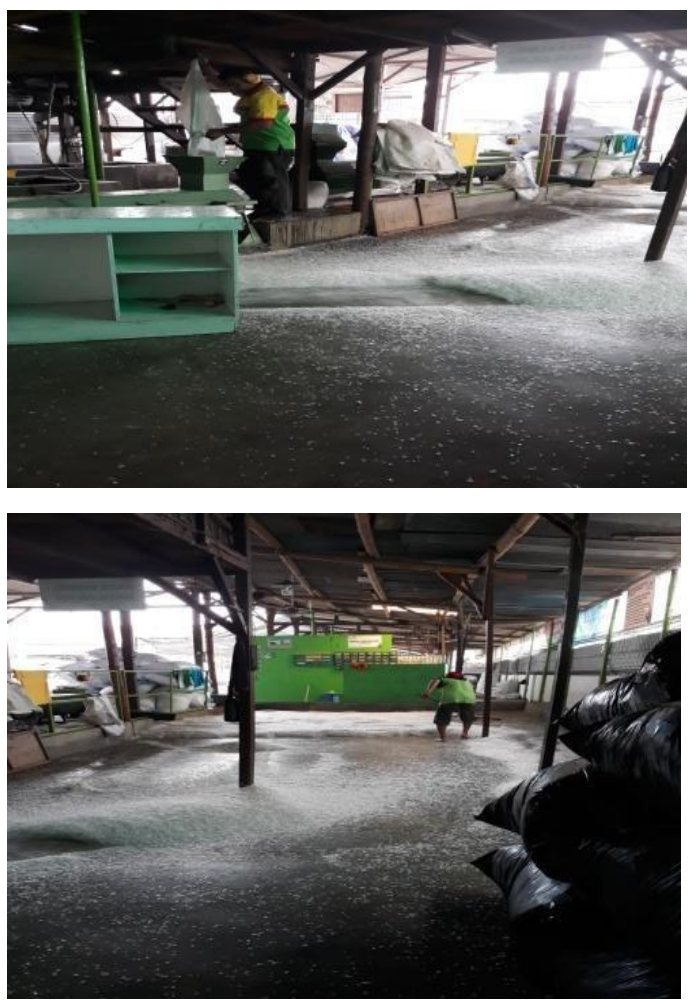

Sumber: Dokumentasi Peneliti (2020)

a. Penjualan Produk sampah

Dalam satu hari, BSM dapat memperoleh 
sekitar \pm 4 ton per hari dari jumlah total transaksi sekitar \pm Rp.3.000.000,- hingga Rp.4.000.000,- per hari. Sedangkan untuk penerimaan penjualan sampah baik dari sampah yang dicacah/giling maupun yang tidak dicacah sebesar \pm 250 juta dengan keuntungan $\pm 40-50$ juta perbulan BSM menjual produk sampahnya menjadi tiga produk sampah yaitu bahan baku, kerajinan daur ulang, dan produksi cacah plastik. Bahan baku merupakan produk plastik yang tidak melalui proses pencacahan yaitu plastik, logam, kertas, dan botol kaca. Bahan baku ini akan langsung dijual ke lapak/pengepul/pabrik setelah disortir oleh BSM. Untuk produk berupa kerajinan daur ulang tidak semua sampah dapat dijadikan kerajinan. Hanya sampah-sampah tertentu saja yang dapat dijadikan kerajinan seperti kertas Koran dapat dibuat menjadi vas bunga, kain percah menjadi dompet, styrofoam menjadi bahan dasar lukisan, plastik menjadi macam-macam tas, dan sebagainya. Pada kerajinan daur ulang ini, pembuatan kerajinan tidak dilakukan oleh BSM melainkan dikelola sendiri oleh nasabah. Sehingga kerajinan yang dijual di BSM hanya berupa titipan dari nasabah yang ingin memasarkan produk kerajinannya di BSM. Sedangkan cacahan plastik akan dilakukan oleh BSM sendiri, biasanya sudah dipesan oleh supplier atau pabrik plastik.
Dari ketiga produk sampah yang dijual oleh BSM tersebut, produk yang memiliki daya jual tinggi adalah produk bahan baku dan produksi/cacah plastik. Sedangkan produk kerajinan daur ulang memiliki penjualan tidak menentu karena tergantung pada tamu/kunjungan ke BSM menjadi tujuan dalam studi banding kabupaten/kota di Indonesia baik dari pemerintah daerah, LSM/NGO, organisasi sosial masyarakat, CSR, dan lainnya terkait Bank Sampah, karena menurut Kementrian Lingkungan Hidup dan Kehutanan, BSM adalah bank sampah terbaik yang ada di Indonesia. Selain itu kegiatan penjualan kerajinan daur ulang ini juga dibeli oleh pemerintah Kota Malang terutama DKP Kota Malang sebagai pengganti tas dari kegiatan pelatihan 3R yang dilaksanakan oleh DKP Kota Malang. Berikut gambar display BSM yang digunakan khusus untuk kerajinan.

\section{Gambar 4. Display Barang Hasil Daur Ulang di Kantor BSM}

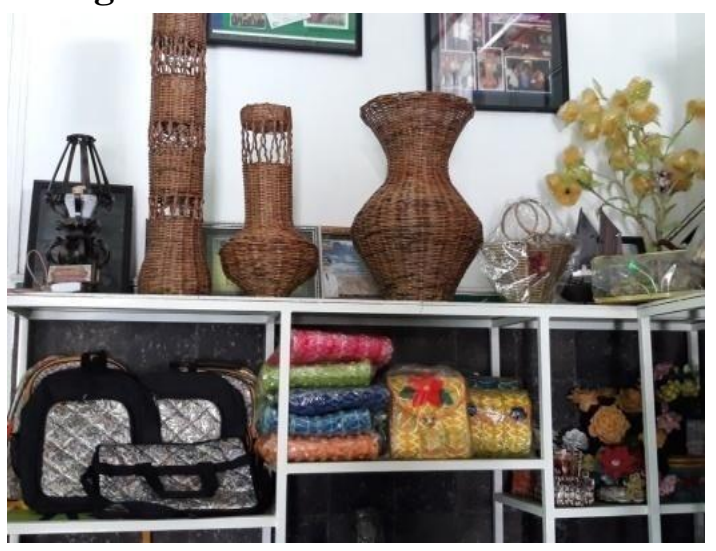




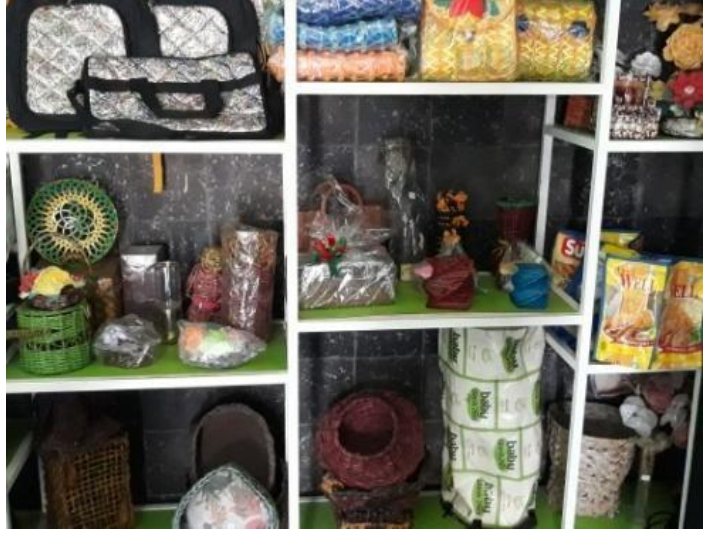

Sumber: Dokumentasi Peneliti (2020)

\section{PENUTUP}

Pemerintah terus melakukan upaya pengelolaan sampah menggunakan konsep 3R (Reduce, Reuse, Recycle). Kegiatan ini dibuktikan dengan adanya Bank Sampah Malang, Pengkomposan, dukungan kepada pemulung. Pemerintah selalu berupaya memberikan edukasi kepada masyarakat tentang pengelolaan sampah rumah tangga dan sadar untuk membuang sampah pada tempatnya. Maka dari itu, pemerintah dan pihak yang berwenang perlu memberikan sanksi terhadap pelanggar aturan.

\section{DAFTAR PUSTAKA}

Anderson, James. E. 2003. Public Policy Making, Fifth Edition. USA: Houghton Mifflin Company.

Cointreau, S.J., C.G. Gunnerson, J.M. Huls, dan N.N Seldman. 1985. Integrated

resource recovery: Recycling from municipal refuse - A state-of-the- art review and annotated biobliography. UNDP Project Management Report Number 1. The World Bank, Washington D.C. Badan Pusat Statistik. 2015. Volume dan Pengolahan Sampah. https://malangkota.bps.go.id/.

Diakses tangga 7 Agustus 2019, pukul 11.25 WIB

Haerul, Akib, H., \& Hamdan. 2016. Implementasi Kebijakan Program Makassar Tidak Rantasa di Kota Makassar. Jurnal Administrasi Publik, 6, 21-34. Retrieved from http://ojs.unm.ac.id/index.php/iap/a rticle/view/2477/1272

Iskandar, J. 2012. Kapita Selekta teori Administrasi Negara. Bandung: Puspaga.

Godin, R. E., Rein, M., \& Moran, \&. M. 2006. The Public and its Policies. In M. Moran, M. Rein, \& R. E. Goodin, The Oxford Handbook ff Public Policy (pp. 3-35). New York: Oxford University Press.

Kementerian Lingkungan Hidup. 2008. Gender dan lingkungan hidup.http://www.menlh.go.id/hom e/index.php?option=com_content\& view=artcle \&id=2916:GENDERDAN-

LINGKUNGANHIDUP\&catid=43: berita\&Itemid=73\&lang=en . 
Moningka, L. 2000. Community participation in solid waste management factors favouring the sustainability of community participation: A literature review. UWEP Occasional Paper.

Ostrom, E., 1990. Governing the commons: The evolution of institutions for

collective action. Cambridge University Press, U.S.A.

Tobing, ISL. 2005. Dampak sampah terhadap kesehatan lingkungan dan manusia. Makalah pada Lokakarya "Aspek lingkungan dan legalitas pembuangan sampah serta sosialisasi pemanfaatan sampah organik sebagai bahan baku pembuatan kompos" kerjasama Universitas Nasional dan Dikmenti DKI, Jakarta.

Thoha, M. 2012. Dimensi-dimensi Prima Ilmu Administrasi Negara. Jakarta: Raja Grafindo Persada

Wahab, S. A. 2010. Pengantar Analisis Implementasi Kebijakan Negara. Jakarta: Rineka Cipta.

Wahyudi, A. 2016. Implementasi rencana strategis badan pemberdayaan masyarakat dan desa dalam upaya pengembangan Badan Usaha Milik Desa di Kabupaten Kotawaringin Barat. Jurnal Ilmiah Administrasi
Publik , 2(2), 101-105. Retrieved from

http://ejournalfia.ub.ac.id/index.ph p/jiap/article/view/566/851

Winarno, B. 2012. Kebijakan Publik: Teori, Proses, dan Studi Kasus. Jakarta: Center for Academic Publishing Service.

\section{Peraturan:}

Peraturan Daerah Kota Malang Nomor 10 Tahun 2010.

Undang-Undang No.18 Tahun 2008 tentang Pengelolaan Sampah. 